\title{
EFFECT OF PHYSICAL ACTIVITY ON CARDIOMETABOLIC MARKERS IN ADOLESCENTS: SYSTEMATIC REVIEW
}

\author{
EFEITO DA ATIVIDADE FÍSICA SOBRE OS MARCADORES CARDIOMETABÓLICOS \\ EM ADOLESCENTES: REVISÃO SISTEMÁTICA
}

Review Articles

ARTIGO DE REVISÃO

ARtículos de REVISIÓN

\author{
EFECTO DE LA ACTIVIDAD FÍSICA SOBRE LOS MARCADORES CARDIOMETABÓLICOS \\ EN ADOLESCENTES: REVISIÓN SISTEMÁTICA
}

\begin{abstract}
Valter Paulo Neves Miranda' (Educador físico)

Paulo Roberto dos Santos Amorim² (Educador físico)

Nathália Cristina Borges Oliveira ${ }^{2}$

(Educadora física)

Maria do Carmo Gouveia Peluzio' (Nutricionista)

Silvia Eloiza Priore

(Nutricionista)

1. Universidade Federal de Viçosa, Departamento de Nutrição e Saúde, Programa de Pós-Graduação em Ciência da Nutrição, Viçosa, $M G$, Brasil.
\end{abstract}

2. Universidade Federal de Viçosa, Departamento de Educação

Física, Laboratório de Performance Humanas, Viçosa, MG, Brasil.

\section{Correspondência:}

Universidade Federal de Viçosa Av. P.H Rolfs, Programa de PósGraduação em Ciência da Nutrição, Centro de Ciência Biológica II, $5 \circ$ andar, Viçosa, MG, Brasil. 570-900. vpnmiranda@yahoo.com.br.

\begin{abstract}
The accumulation of body fat is a major risk factor for cardiometabolic diseases. Obesity can be considered a chronic systemic inflammatory disease in adults and younger people. The control of subclinical inflammation process through the practice of physical activity (PA) can mitigate the effects of risk factors that trigger atherosclerosis that worsens with advancing age. The objective of this study was to conduct a systematic review of the influence of physical activity and/or exercise on cardiometabolic markers and othrer risk factors of cardiovascular disease in adolescents. A systematic review was conducted in electronic databases Scopus, Pubmed, Conchrane Collection and SciELO. The terms used in the search were "cardiovascular diseases AND inflammation AND adolescents AND physical activity OR exercise". A total of 24 original articles were evaluated, being 14 longitudinal and 10 cross-sectional studies. Overall, 16 articles (66.66\%) showed that PA, exercise and/or sedentary behavior may have influenced or have been related to the concentration of cardiometabolic markers. All studies that examined lifestyle changes showed reduction of cardiometabolic markers. Some limitations were observed: reduced samples, lack of dietary prescription, evaluation and control of volume and intensity of exercise. Most of the studies analyzed showed that the physical activity could influence and decrease the concentrations of cardiometabolic markers in adolescents. However, studies with representative sample size and precise control in assessing the level of physical activity and/or exercise are required to determine accurately the changes that the more active lifestyle can bring on inflammatory process, as well as other risk factors for cardiometabolic diseases in adolescents.
\end{abstract}

Keywords: adolescent; biomarkers; cardiovascular diseases; metabolism.

\section{RESUMO}

O acúmulo de gordura corporal é um dos principais fatores de risco de doenças cardiometabólicas. A obesidade pode ser considerada uma doença inflamatória sistêmica crônica em adultos e em pessoas mais jovens. O controle do processo de inflamação subclínica por meio da prática de atividade física (AF) pode atenuar os efeitos dos fatores de risco que desencadeiam a aterosclerose que se agrava com a idade. O objetivo deste estudo foi realizar uma revisão sistemática sobre a influência da atividade física elou do exercício sobre marcadores cardiometabólicos e outros fatores de risco de doenças cardiovasculares em adolescentes. A revisão sistemática foi realizada nas bases de dados eletrônicas Scopus, Pubmed, Conchrane Collection e SciELO. Os termos usados para a busca foram "cardiovascular diseases AND inflammation AND adolescents AND physical activity OR exercise". Foram avaliados 24 artigos originais, 14 estudos longitudinais e 10 transversais. No geral, 16 artigos (66,66\%) mostraram que a AF, o exercício físico e/ou comportamento sedentário influenciaram ou se relacionaram com a concentração de marcadores cardiometabólicos. Todos os estudos que analisaram mudanças do estilo de vida mostraram redução dos marcadores cardiometabólicos. Algumas limitações foram observadas: amostras pequenas, falta de prescrição dietética, controle e avaliação de volume e intensidade do exercício físico. A maioria dos estudos analisados mostrou que a atividade física pode influenciar e diminuir as concentrações dos marcadores cardiometabólicos em adolescentes. No entanto, estudos com tamanho amostral representativo e com controle da avaliação do nível de atividade e/ou exercício físico são necessários para verificar com acurácia as alterações que o estilo de vida mais ativo pode apresentar no processo de inflamação, assim como em outros fatores de risco de doenças cardiometabólicas em adolescentes.

Descritores: adolescente; biomarcadores; doenças cardiovasculares, metabolismo.

\section{RESUMEN}

La acumulación de grasa corporal es uno de los principales factores de riesgo de enfermedades cardiometabólicas. La obesidad puede ser considerada como una enfermedad inflamatoria sistémica crónica en adultos y en los jóvenes. El control del proceso de inflamación subclínica a través de la práctica de actividad física (AF) puede mitigar los efectos de los factores de riesgo que desencadenan la aterosclerosis, que empeora 
con la edad. El objetivo de este estudio fue realizar una revisión sistemática de los efectos de la actividad física y/o ejercicio sobre los marcadores cardiometabólicos y otros factores de riesgo de enfermedades cardiovasculares en adolescentes. La revisión sistemática se realizó en las bases de datos electrónicas Scopus, Pubmed, Conchrane Collection y SciELO. Los términos utilizados en la búsqueda fueron "cardiovascular diseases AND inflammation AND adolescents AND physical activity OR exercise". Fueron evaluados 24 artículos originales, 14 estudios longitudinales y 10 transversales. En general, 16 artículos (66,66\%) mostraron que la AF, el ejercicio y/o el comportamiento sedentario han influenciado o se relacionado con la concentración de los marcadores cardiometabólicos. Todos los estudios que examinaron el cambio de estilo de vida mostraron una reducción de los marcadores cardiometabólicos. Se observaron algunas limitaciones: muestras pequeñas; falta de prescripción dietética; control y evaluación del volumen y de la intensidad del ejercicio. La mayoría de los estudios analizados demostraran que la actividad fisica puede influenciar y disminuir las concentraciones de marcadores cardiometabólicos en los adolescentes. Sin embargo, se requieren estudios con tamaño representativo demuestra y que avalúen el control del nivel de actividad física y/o ejercicio para determinar con precisión los cambios que el estilo de vida más activo puede presentar en el proceso de inflamación, así como otros factores de riesgo de enfermedades cardiometabólicas en adolescentes.

Descriptores: adolescente; biomarcadores; enfermedades cardiovasculares; metabolismo.

\section{INTRODUCTION}

Adolescence is a transition from childhood to adult phase, in which growth and maturational development occur in ascending order. According to Rasmussen et al.', the pubertal development includes a multitude of physiologic and psychological changes, which strongly affect observations linked to outcome parameters such as biology, behavior, and intellectual performance. Some changes that take place in this phase can influence behavior in physical, cognitive and social aspects, including the adoption of a sedentary lifestyle and poor eating habits ${ }^{2}$.

The adoption of a sedentary lifestyle, with low levels of physical activity (PA) and a hypercaloric diet and low fiber intake are important factors for increasing prevalence of overweight, obesity and, consequently, metabolic disorders ${ }^{3,4}$. The rapid increase in prevalence and severity of obesity in younger individuals is likely to increase cardiovascular diseases incidence worldwide ${ }^{5}$. It is estimated that $20 \%$ of teens from western countries are overweight or obese ${ }^{6}$.

The subclinical inflammation process is a set of biochemical, physiological and immunological alterations in response to aggressive stimuli to organism? ${ }^{7}$. Inflammation may change the risk for cardiovascular disease by its association with traditional cardiovascular diseases (CVD) such as high density lipoprotein, or inflammation may have a direct effect on the endothelium, atherogenesis, atherosclerosis phases, including plaque development, disorders and thrombosis ${ }^{8}$.

However, the CVD that initiate prematurely can get worse as the time goes by until adult phase ${ }^{8,9}$. There is an association among childhood obesity, cardiovascular disease and biomarkers produced from adipose tissue and with other roles in inflammation and oxidative stress are increasingly being studied. Results have pointed to specific therapeutic strategies CVD prevention development at early age ${ }^{10}$.

Healthy behavior such as PA, decrease of sedentary behavior and nutritional education may can diminish the concentration of inflammatory cytokines and / or increasing anti-inflammatory cytokines in adolescents $5^{8,1,12}$.

The increase in glucose uptake and insulin sensitivity in muscle can be stimulated by PA level increasing ${ }^{13}$. The lipoprotein lipase enzyme $(\mathrm{LPL})$ controls fat stock, and PA increases the ability to release and storage energy of adipose tissue, as the capacity of carbohydrates and fat oxidation from muscle. The adipocytes excess in bloodstream, is related to the metabolic syndrome factors, and produce cytokines tumor necrosis factor a (TNF-a) and Interleukin-6 (IL-6) ${ }^{14}$.

Currently, despite a growing number of studies that analyzes the action and effectiveness of the PA and exercise on cardiometabolic markers in obese adolescents ${ }^{9-12,14,15}$. Also, there are few studies of systematic review describing intervention procedures with PA in cardiometabolic markers and risk factors of CVD in adolescents. Thus, the objective this study was to realize a systematic review study regarding the influence of physical activity and / or exercise on cardiometabolic markers and others risk factors of cardiovascular disease in adolescents.

\section{MATERIAL AND METHODS}

It was included complete original scientific articles and studies that deal with studies with assessment or relation of physical activity and / or exercise with cardiometabolic markers in adolescents. Review articles and meta-analyzes, thesis, book chapters, books, medical books, commentaries, reviews, government information, and also original articles with animals or who used medicaments were excluded. The process involved scientific articles research of the following databases: Scopus, Pubmed, Conchrane Collection e Scielo. Preferred Reporting Items for Systematic Reviews and Meta-Analyses (PRISMA) ${ }^{16}$ guidelines were followed for this systematic review elaboration.

As descriptors, it was used the associated terms "cardiovascular diseases AND inflammation AND adolescents AND physical activity OR exercise". All associated terms are indexed in Health Science Descriptors system (DeCs/MeSH).

\section{Statistical analysis}

Research period was not present because it aimed to investigate original scientific articles published over time, associated with cardiometabolic markers and physical activity.

After the selection of the papers, the titles were analyzed and the abstracts selected realized a floating reading ${ }^{17}$, and only those considered relevant to the study were selected. Selected articles summaries were analyzed by identifying the studies type, population investigated, methodological aspects (including instruments adequacy in the sample) and conceptual perspective related to cardiometabolic markers. First, results were presented in general way, and subsequently were separately described according to delimitation.

Only one reviewer (VPNM) analyzed all titles produced by the initial searches and excluded those that were definitively irrelevant to the search intent. The titles that were insufficiently clear to make such a determination were retained for review at the abstract level. The remaining 
abstracts were then independently screened for two reviewers (VPNM and $\mathrm{NCBO}$ ), being analyzed mainly the methods and main results.

The full article was obtained for all potentially relevant abstracts. First, the data extraction was conducted for one reviewer (VPNM), and after, other reviewer checked all information for continue analyzing the results. The full papers were evaluated according to the following criteria: name of the researchers, publication's year, name of the journal, description of the sample, methods of physical activity and / or exercise used and main results in relation to cardiometabolic markers.

\section{RESULTS}

In the first search step were identified 323 references, articles number in each descriptors combination. The Figure one represents a flowchart of items selection procedure, until the final result of 24 articles, with 14 articles in longitudinal design with intervention and 10 articles in cross-sectional design (Figure 1).

Overall, 16 of 24 selected articles (66.66\%) showed that PA, physical exercise and / or sedentary behavior may influence or relate to the concentration of cardiometabolic markers, with most studies involving evaluation of adolescents with overweight and obesity.

C-reactive protein (CRP) was the marker that had higher association with PA. In 6 studies $^{18-23}$ there was a decrease in the concentration of CRP, and in one study only ${ }^{24}$ there was an increased after the intervention with PA. In addition to PCR, there was a decrease in $\gamma$-fibrinogen, retinol carrier protein (RBP4), IL-6 e PAI-1.

Regarding the articles with longitudinal design, it was found that of 14 selected articles, 11 showed effect (decrease or increase) in cardiometabolic markers ${ }^{18-22,25-27}$ PA intervention programs period ranged from seven weeks ${ }^{9}$ to one year ${ }^{28}$. (Table 1).

Lifestyle changing was the proposal used by seven of longitudinal studies 2,18,20-22,27-31. In all these studies there was an cardiometabolic markers reduction (Table 1).

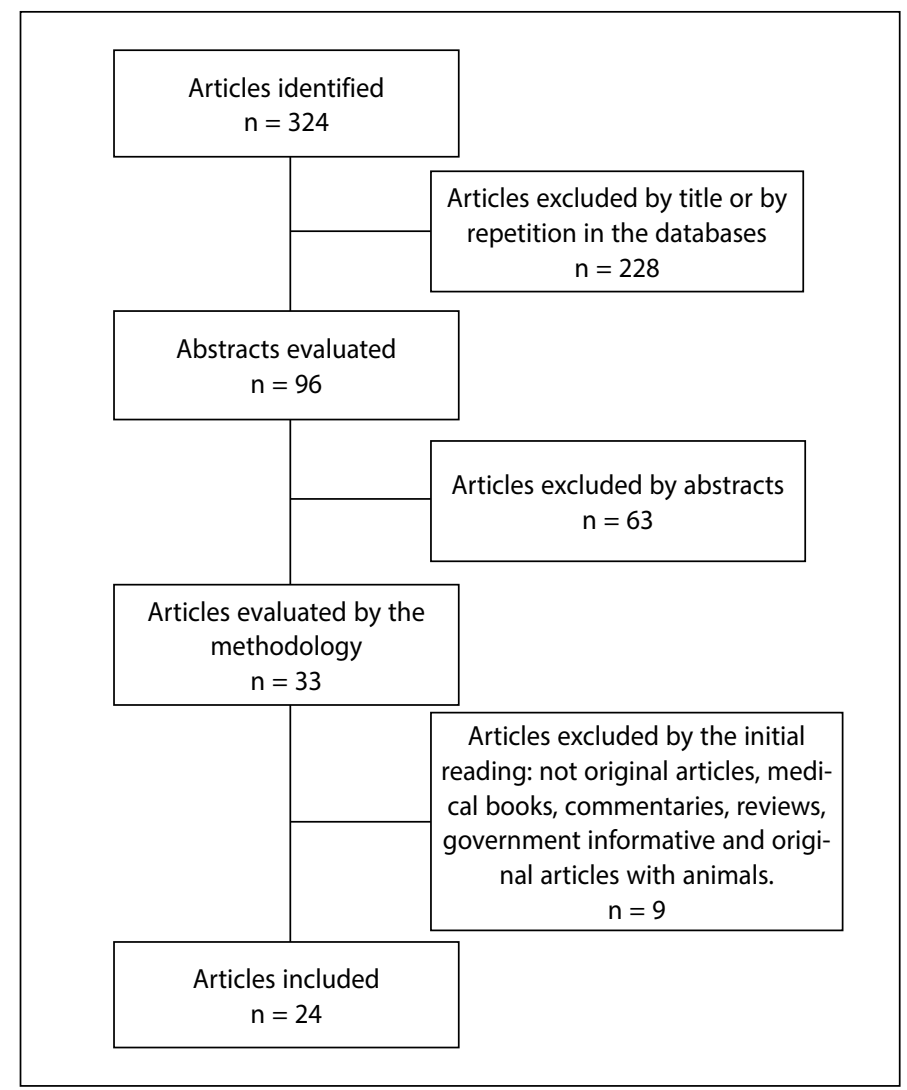

Figura 1. Tempo sentado de acordo com a duração do sono dos adolescentes.
PA programs used mainly aerobic exercise as a stimulus to increase AP level|21,22,27,29,30. Intense and moderate exercises were also used $^{18,19,24,30-33}$ planned exercises and sports games ${ }^{29}$ and controlled exercises in exercise bike ${ }^{31}$ besides sedentary behavior evaluation ${ }^{20}$. Longitudinal studies also assessed cardiorespiratory fitness by different methods: ergospirometry test ${ }^{29}, 20$ m shutle-run test ${ }^{9}$ and cardiorespiratory test on exercise bike ${ }^{32,33}$. A study has used indirect calorimetry test for evaluating metabolic rate ${ }^{19}$.

It was observed that 10 articles were selected with cross-sectional design, among them, five showed a relationship between physical activity level, body composition and cardiometabolic markers 12,23,25,32-36 (Table 2). Two studies showed an association between sedentary behavior and cardiometabolic markers ${ }^{25,34}$. Overweight status and insulin resistance were associated with higher levels of inflammation (high-sensitive $P C R \geq 1 \mathrm{mg} / \mathrm{L}$ ) and cardiovascular risk according to arterial indices $^{23}$ (Table 2).

Questionnaires were methods most used to evaluate the PA level in cross-sectional studies. Other studies have used accelerometer as evaluation method for PA level ${ }^{12,25,35}$ and pedometer ${ }^{19}$.

\section{DISCUSSION}

After careful evaluation of this review articles, it was found that 16 (66.66\%) of them have shown that PA may influence or relate to some cardiometabolic markers concentration. And that this relationship between PA and the inflammatory process may occur directly or indirectly, when PA proves efficient in reducing risk factors for CVD related inflammatory markers, such as obesity, diabetes, lipid profile imbalance, insulin resistance and hypertension.

Vasconcellos et al. ${ }^{15}$ point the PA as an effective strategy in preventing obesity and comorbidities correlated to body fat excess only in obese and overweight adolescents. However, it is emphasized that many of the results need to be observed cautiously by the lack of description of appropriate exercise prescription considering type, intensity and volume. In this review, it was verified positive effect of PA in cardiometabolic markers not only in obese adolescents, but also in lean adolescents, from both sex.

CVD risk factors can be defined as measurable characteristics, that have a genetic predisposition, and behavioral of an individual. Manifestations, such as heart attack and stroke, not emerge only in adulthood, CVD risk factors can be present during childhood and adolescence ${ }^{36}$. These are particularly important because they help identify asymptomatic individuals who have a greater chance for developing the disease in future, compared to the general population.

Lipid accumulation, inflammatory cells and fibrous elements that are deposited on arterial walls are responsible for fatty streaks and plaques that often cause blockage in blood vesse ${ }^{37}$ Excess body fat provides metabolic disorders and activates the subclinical inflammation process, which can trigger or exacerbate this process. These conditions, in addition to predispose individuals to atherosclerosis can induce a pro-inflammatory phenotype and prothrombotic endothelium ${ }^{41,42}$

PCR was the marker that suffered more influence of physical activity programs. This is considered the main acute phase protein, synthesized by liver and regulated by cytokines, IL-6, o TNF-a and a IL-1, predominantly. CRP levels modest elevations are also present in chronic inflammatory conditions such as atherosclerosis, and their levels tripled in risk presence of peripheral vascular disease ${ }^{43}$. One of its most important functions is its ability to bind to cell membrane components, forming complexes that activate opsonin release and phagocytosis and eventual removal of these traffic structures ${ }^{44}$.

PCR can bind to complement factor (C3 and C4), increasing 
Table 1. Longitudinal and randomized controlled trial articles available on databases Scopus, Pubmed, Conchrane Collection and SciELO. These studies evaluated the effects of physical activity on cardiometabolic markers.

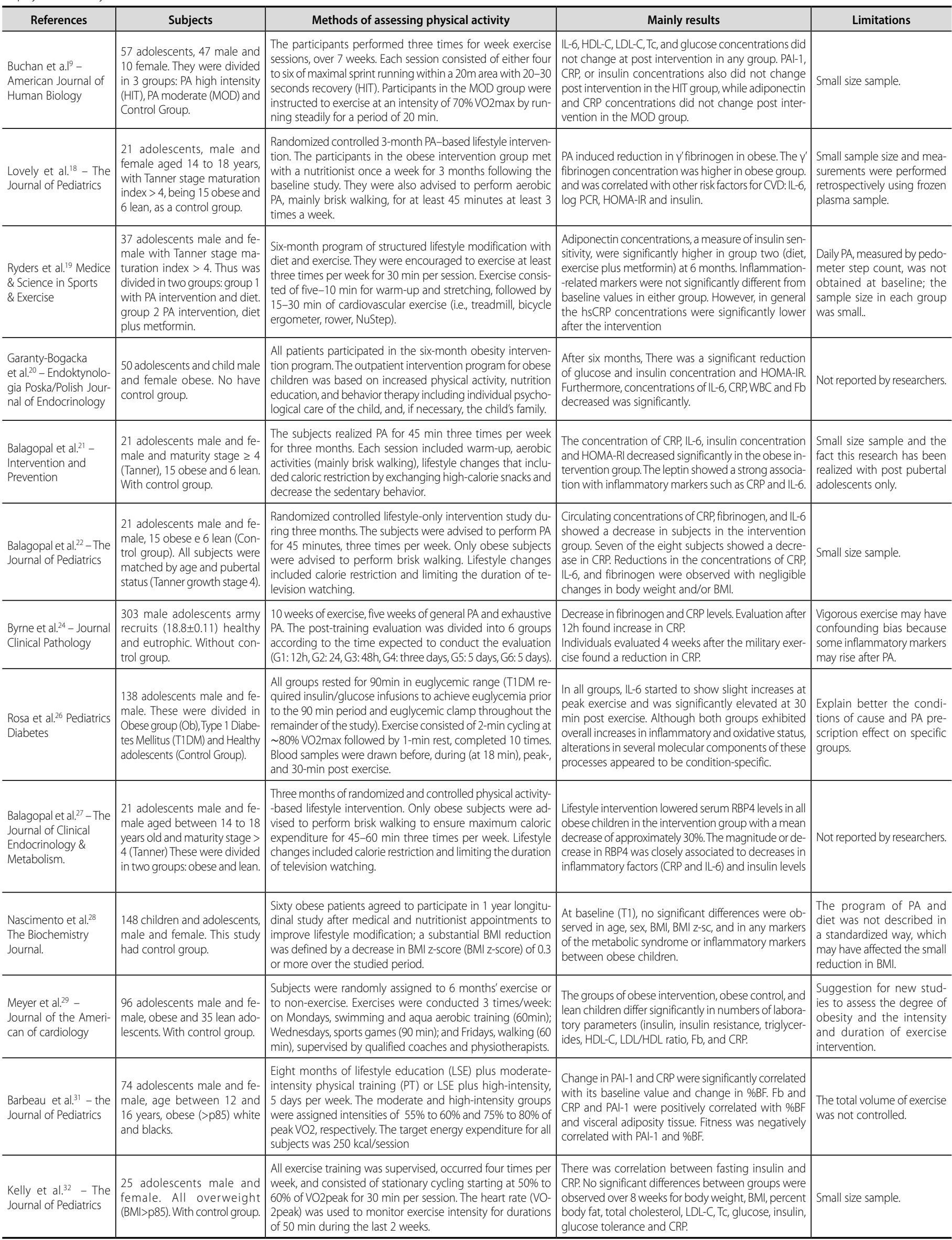

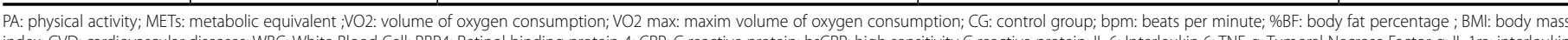

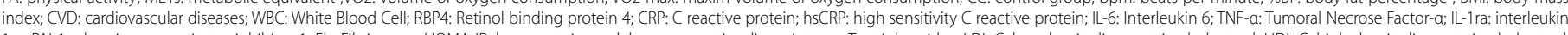

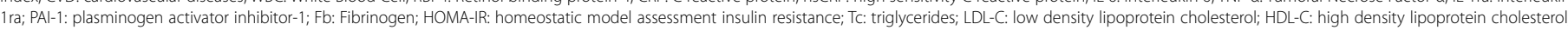
DM: Diabetes Mellitus; T2DM: Type 2 Mellitus Diabetes, T1MD: Type1 Mellitus Diabetes. 
Table 2. Cross-sectional articles available on data bases Scopus, Pubmed, Conchrane Collection and SciELO. These studies evaluated the relationship between physical and cardiometabolic markers.

\begin{tabular}{|c|c|c|c|c|}
\hline References & Subjects & Methods of assessing Physical Activity & Mainly Results & Limitations \\
\hline $\begin{array}{l}\text { Martinez-Gomez } \\
\text { et al. }{ }^{12} \text { Atherosclerosis }\end{array}$ & 1025 male and female adolescents. & $\begin{array}{l}\text { Evaluation of physical activity level by accelerom- } \\
\text { etry (ActiGraph) during seven days. The variable } \\
\text { PA was counted per minute (cpm): } 2000 \mathrm{cpm} \\
\text { moderate and vigorous } 4000 \mathrm{cpm}) \text {. Use the IPAq } \\
\text { for teenagers. Physical fitness test 20m Shuttle-run. }\end{array}$ & $\begin{array}{l}\text { All objective assessment of the PA group and vigorous } \\
\text { IPAq was significantly associated with CRP, comple- } \\
\text { ment factor } 3 \text { and } 4 \text {. Physical fitness test was signifi- } \\
\text { cantly associated with C } 3 \text { and C4 independent of BMI. }\end{array}$ & $\begin{array}{l}\text { Food intake was not observed } \\
\text { during the time watching televi- } \\
\text { sion and the threshold of these } \\
\text { results should be considered. }\end{array}$ \\
\hline $\begin{array}{l}\text { Velásquez-Rodríguez } \\
\text { et al.23 - Biomed Cen- } \\
\text { tral Pediatrics }\end{array}$ & $\begin{array}{l}120 \text { adolescents male and female } \\
\text { aged } 12 \text { to } 18 \text { years, divided in } \\
\text { three groups: overweight group } \\
\text { with insulin resistance, overweight } \\
\text { group without insulin resistance, } \\
\text { and control group. }\end{array}$ & $\begin{array}{l}\text { The Three-DPAR method was applied. MET values } \\
\text { for each activity were calculated based on the Ame- } \\
\text { rican College of Sports Medicine Compendium of } \\
\text { PA. The sedentary behavior was for evaluated for } \\
\text { time spent watching television/playing video ga- } \\
\text { mes: }>3 \text { hours per day. }\end{array}$ & $\begin{array}{l}\text { Overweight status and insulin resistance were asso- } \\
\text { ciated with higher levels of inflammation (hsCRP } \geq 1 \\
\mathrm{mg} / \mathrm{L} \text { ) rising in } 1.6 \text { times the cardiovascular risk. When } \\
\text { they reached a waist circumference }>\text { p } 95 \text { and wa- } \\
\text { tched } 3 \text { or more hours/day of television. The PA level } \\
\text { had reverse relationship with HOMA index. }\end{array}$ & $\begin{array}{l}\text { The } 24 \text {-h food consumption ques- } \\
\text { tionnaire properly reflects popu- } \\
\text { lation food consumption and PA } \\
\text { was assessed in young people } \\
\text { using questionnaire method. }\end{array}$ \\
\hline $\begin{array}{l}\text { Martinez-Gomez } \\
\text { et al. }{ }^{25} \text { - The Journal of } \\
\text { Pediatrics }\end{array}$ & $\begin{array}{l}183 \text { male and female adolescents, } \\
\text { PA participants P as a Preventi- } \\
\text { ve Measure Against Overweight, } \\
\text { Obesity and chronic diseases. }\end{array}$ & $\begin{array}{l}\text { Evaluation of physical activity level by accelerome- } \\
\text { try (ActiGraph) used during seven days. Sedentary } \\
\text { behaviors were evaluated (TV time, video game } \\
\text { playing and painting). The validated data were the } \\
\text { last } 10 \mathrm{~h} \text { of the last four days and one of those over } \\
\text { the weekend. }\end{array}$ & $\begin{array}{l}\text { It was found association between sedentary behavior } \\
\text { and cardiometabolic markers. Time watching television } \\
\text { was associated with soluble endothelial adhesion mo- } \\
\text { lecules (ICAM, VCAM, E-selectin and L-selectin). }\end{array}$ & $\begin{array}{l}\text { Cross-sectional study did not } \\
\text { allow assessment of the reaction } \\
\text { caused by resistin with other car- } \\
\text { diometabolic markers. }\end{array}$ \\
\hline $\begin{array}{l}\text { Ischander et al. }{ }^{33}- \\
\text { Official Journal of the } \\
\text { American College of } \\
\text { Sports Medice }\end{array}$ & $\begin{array}{l}74 \text { female healthy adolescents, } \\
\text { aged } 14 \text { to } 17 \text { years. Two groups: } \\
\text { sedentar and active adolescents } \\
\text { who practiced any sport. }\end{array}$ & $\begin{array}{l}\text { PA level was evaluated by Three-DPAR. The PA } \\
\text { level was classified according the Compedium de } \\
\text { Aisworth: lights (<3 METs), moderate (3-6METs) e } \\
\text { vigorous ( }>6 \mathrm{MET}) \text {. Cardiovascular fitness test on a } \\
\text { cycle ergometer test to the limit exercise tolerance. }\end{array}$ & $\begin{array}{l}\text { IL-6, IL-1ra and TNF-a had significantly higher concen- } \\
\text { trations of inactive groups. The PCR was high in the } \\
\text { sedentary group. }\end{array}$ & $\begin{array}{l}\text { Small size sample. And not ex- } \\
\text { plored factors such as gender, } \\
\text { ethnicity, habitual level of PA } \\
\text { and adiposity. }\end{array}$ \\
\hline $\begin{array}{l}\text { Countryman et al. }{ }^{34}- \\
\text { Annals of Behavioral } \\
\text { Medicine }\end{array}$ & $\begin{array}{l}367 \text { male and female adolescents, } \\
\text { aged } 15 \text { to } 17 .\end{array}$ & $\begin{array}{l}\text { Seven-Day Physical Activity Recall. Description of } \\
\text { activities, duration and intensity. Time evaluation of } \\
\text { sleep and indirect estimate of energy expenditure. }\end{array}$ & $\begin{array}{l}\text { PA and sleep were significantly correlated and there } \\
\text { was a significant partial correlation for the metabolic } \\
\text { syndrome and CRP, IL-6 and Fb. }\end{array}$ & $\begin{array}{l}\text { The associations among PA, sleep, } \\
\text { and cardiometabolic variables } \\
\text { may have been attenuated due } \\
\text { to self-reported PA. }\end{array}$ \\
\hline $\begin{array}{l}\text { Maggio et al. }{ }^{35}-\text { The } \\
\text { Journal of Pediatrics }\end{array}$ & $\begin{array}{l}129 \text { male and female adolescents, } \\
\text { divided in two groups: obese }(n=67) \\
\text { and lean adolescents ( } n=62) \text {. }\end{array}$ & $\begin{array}{l}\text { The PA level was evaluated for uniaxial accelero- } \\
\text { meter. (ActiGraph). }\end{array}$ & $\begin{array}{l}\text { Resistin was negatively correlated with PA levels in all } \\
\text { and also when separated obese non obese. Resistin } \\
\text { was associated with IL-6 and endothelial biomarker. }\end{array}$ & $\begin{array}{l}\text { There was no assessment of sex } \\
\text { hormones. }\end{array}$ \\
\hline $\begin{array}{l}\text { Nadeau et al. } .^{37}- \\
\text { Endocrine Care }\end{array}$ & $\begin{array}{l}47 \text { male and female adolescents, } \\
\text { aged } 12 \text { to } 19 \text { years, divided in } \\
\text { three groups: keeping the age } \\
\text { and maturity stage }>4 \text {. These } 12 \\
\text { with T2DM; } 13 \text { obese; } 12 \text { control } \\
\text { group( lean). }\end{array}$ & $\begin{array}{l}\text { The 3-DPAR method was applied. MET values for } \\
\text { each activity were calculated based on the American } \\
\text { College of Sports Medicine Compendium of PA. Kine- } \\
\text { tics measured during an exercise with constant load } \\
\text { performed in cycle ergometer with a load of } 85 \% \\
\text { of your lactate threshold for the maximum tilt test. }\end{array}$ & $\begin{array}{l}\text { Peak VO2 was lower in adolescents with T2DM com- } \\
\text { pared to the control group (lean) and obese. CRP and } \\
\text { IL-6 were higher in adolescents with T2DM compared } \\
\text { to obese and control groups. }\end{array}$ & $\begin{array}{l}\text { The research did not provide } \\
\text { conclusive information on the } \\
\text { role of RI as an independent } \\
\text { contributor to exercise disorders } \\
\text { in adolescents. }\end{array}$ \\
\hline $\begin{array}{l}\text { Wang et al. }{ }^{38}-\text { Articles } \\
\text { Epidemiology }\end{array}$ & $\begin{array}{l}305 \text { male and female adolescents, } \\
\text { divided in two groups: overweight } \\
\text { and lean adolescents. }\end{array}$ & $\begin{array}{l}\text { A modified Paffenbarger PA questionnaire was used } \\
\text { to estimate energy expenditure. Dietary intake was } \\
\text { assessed by a } 127 \text {-item Willett, food frequency } \\
\text { questionnaire, from which intakes of total energy } \\
\text { and nutrients for each participant were estimated. }\end{array}$ & $\begin{array}{l}\text { Overweight adolescents had higher levels of TNF-a } \\
\text { and CRP, while the level of adiponectin was signifi- } \\
\text { cantly higher in normal weight adolescents. Among } \\
\text { overweight higher levels of PL (phospholipids) dairy } \\
\text { fatty acids were associated with lower CRP. }\end{array}$ & $\begin{array}{l}\text { Limitation in the evaluation } \\
\text { study to interpret the comple- } \\
\text { tion of temporality and cau- } \\
\text { sality relations. }\end{array}$ \\
\hline $\begin{array}{l}\text { Steene-Johannessen } \\
\text { et al. } .^{39} \text { - International } \\
\text { Pediatric Obesity }\end{array}$ & $\begin{array}{l}2299 \text { male and female children and } \\
\text { adolescents, aged } 9 \text { to } 15 \text { years. } \\
\text { These were divided in two groups: } \\
\text { the highest waist circumference } \\
\text { (HW) (40), and a random sample } \\
\text { of } 40 \text { control group. }\end{array}$ & $\begin{array}{l}\text { Aerobic capacity test (VO2): exhaustion test per- } \\
\text { formed on a cycle ergometer. Heart rate was kept } \\
\text { above } 185 \text { bpm. It was created the variable "meta- } \\
\text { bolic risk": the main risk factors involved in the SM } \\
\text { (Tc, HOMA-IR, SBP and HDL-C) turned into Z-score, } \\
\text { calculating waste with age and sex. }\end{array}$ & $\begin{array}{l}\text { CRP, hepatocyte growth factor (HGF) and PAl-1 concen- } \\
\text { tration was significantly higher in the HW group. Partial } \\
\text { correlations controlling for sex, age and pubertal stage } \\
\text { revealed that CRP, HGF and PAl-1 correlated positively } \\
\text { with waist circumference and metabolic risk score, and } \\
\text { negatively with VO2 peak. }\end{array}$ & $\begin{array}{l}\text { Cross-sectional study does not } \\
\text { allow causal explanation. Small } \\
\text { sample may compromise the } \\
\text { power of statistical analysis. }\end{array}$ \\
\hline $\begin{array}{l}\text { Al-Isa AN, et al. }{ }^{40} \\
\text { Atherosclerosis }\end{array}$ & $\begin{array}{l}774 \text { male and female adolescents, } \\
\text { aged } 10 \text { to } 19 \text { years at the Kuwait. }\end{array}$ & $\begin{array}{l}\text { A PA questionnaire evaluating regularly practice } \\
\text { sport, how long they spend a week practicing PA. } \\
\text { To evaluate the diet was used a questionnaire that } \\
\text { assessed a history of diets of the participants. }\end{array}$ & $\begin{array}{l}\text { Boys had higher CRP, ICAM-1, VCAM-1 and HOMA-IR } \\
\text { values. Obese adolescents had higher levels of CRP, } \\
\text { insulin and HOMA-IR. The ICAM-1 was } 3 \text { times higher in } \\
\text { adolescents younger than } 14 \text { years compared to those } \\
\text { aged greater than } 14 \text { years. Obese adolescents had } 33 \\
\text { times the chance of obtaining higher levels of CRP. }\end{array}$ & $\begin{array}{l}\text { The cross-sectional design of the } \\
\text { study and evaluation of socio- } \\
\text { economic level PA and diet was } \\
\text { simple and rude. }\end{array}$ \\
\hline
\end{tabular}

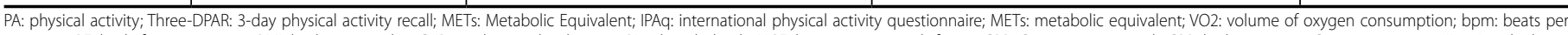

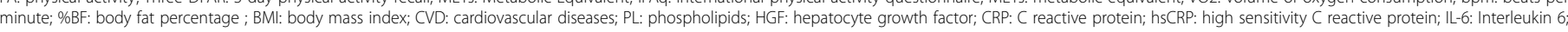

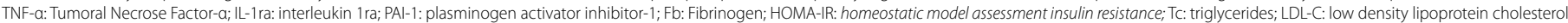
HDL-C: high density lipoprotein cholesterol; T2DM: Type 2 Mellitus Diabetes, T1MD: Type1 Mellitus Diabetes; C3 and C4: Complement Factor 3 and 4; ICAM: intercellular adhesion molecule; VCAM: vascular adhesion molecule.

expression of adhesion molecules, and decrease endothelial vasodilator nitric oxide expression 41. Furthermore, CRP can stimulate expression of thrombosis factor plasminogen activator inhibitor 1 (PAI-1) and can induce oxidative stress and secretion of other cytokines ${ }^{8}$.

Among the articles that correlate with cardiometabolic markers, 11 were longitudinal and five cross-sectional design. The change of lifestyle, through diet and PA, was used by seven longitudinal studies ${ }^{18,20-22,28,29,33}$. Fröhlich et al. ${ }^{45}$ highlighted that treatment programs that combine physical activity, dietary, and behavior therapy components effectively lead to reduced overweight in children and adolescents.

Regarding diet, it is known that food habits characteristics may contribute to the inconclusive evaluation of effect of physical activity on risk factors for CVD. The dietary pattern can have independent PA action and weight reduction compared to several cardiometabolic markers ${ }^{13}$.

The intervention period with PA ranged from seven weeks ${ }^{9}$ to one year ${ }^{28}$. Another systematic review study found that intervention period was not longer than two weeks, being considered a limiting aspect in the proposal to verify change in body composition in obese and overweight adolescents ${ }^{13}$

Lovely et al. ${ }^{18}$. Lovely et al realized their studies through weekly meetings with obese adolescents group were made with a nutritionist for at least 45 minutes three times a week. Intervention program 
significantly decreased the levels of $\gamma^{\prime}$ fibrinogen. Fibrinogen correlates with metabolic syndrome components, promotes venous arterial thrombosis by the increase in fibrin formation, platelet aggregation and plasma viscosity ${ }^{46}$

Ryders et al. ${ }^{19}$ realized a six months PA program with both sexes adolescents, divided into two groups: group one with PA intervention plus diet; group two with PA intervention plus metformin. There was intensive dietary counseling in order to achieve calorie deficit 250-500 calories a day and structured exercise including aerobic exercise (15 minutes) and strength (10 minutes) with 30 minutes per session relying on heating up and relaxation. High-sensitive PCR concentration decreased significantly in all adolescents, adiponectin concentrations, IL-6 and blood glucose decreased significantly in adolescents increased cardiorespiratory fitness.

Nascimento et al. ${ }^{28}$ evalueted obese adolescentes of both sexes and a control group with proper weight. PA program was based on lifestyle change, aiming weight loss based on diet and physical activity encouragement for one year. Even a small reduction in BMI showed improvement in lipid profile and reduction of insulin resistance index. The concentration of PCR was six times higher in obese children that in adolescents in the control group.

Barbeau et al. ${ }^{31}$ proposed a lifestyle change program, the "lifestyle education (LSE)" for 8 months, with obese adolescents of both sexes, black and white. Participants were divided into intervention groups: LSE only; moderate exercise and LSE, and LSE and intense exercise. There were no differences in results of intervention program between the sexes and ethnic groups, but in individuals who reduced body fat percentage (\% BF) there was a decrease in PAI-1.

Intervention on cardiometabolic markers through lifestyle change during adolescence is important because of CVD that begin in youth worsen into adulthood. Garanty-Bogacka et al. ${ }^{20}$ proposed a change lifestyle program, that in addition to physical activity encouragement, involving nutrition education and incentive to decrease sedentary behavior through time spent watching TV or video games. There was a significant reduction of CRP, white cell count and fibrinogen in obese adolescents of both sexes.

Cardiometabolic biomarkers provide important information about vascular cells activation, oxidative stress and leukocytes and macrophages recruitment. Some body cells secrete various cardiometabolic markers, such as vascular, hepatocytes, adipocytes and immune system cells ${ }^{8}$. The behavior of peripheral blood cells involved in inflammation may be a predictor of ischemic cerebrovascular disease and peripheral arterial disease. The white cell count represents one of the recent risk factors for coronary heart disease ${ }^{7}$.

Other studies have evaluated exercise influence on inflammatory markers ${ }^{9,29}$. Buchan et al. ${ }^{8}$ evaluated two groups of adolescents regarding the exercise type, one group with intense PA performed three times a week and other moderate PA for 20 minutes. Results showed that IL-6, high lipoprotein cholesterol (HDL-C), low density lipoprotein cholesterol (LDL-C), total cholesterol and glucose did not change after intervention in both groups, however, there was PAI-1 reduction in both.

Meyer et al. ${ }^{29}$ inserted a physical exercise protocol for six months in adolescents with adequate BMI and obesity, 3 times a week involving swimming and aerobic training in water (60 minutes), sports games and walk (60 minutes). There was also diet orientation made by a nutritionist. After of the intervention was found reduction in fasting insulin levels, insulin resistance, triglycerides, $\mathrm{LDL} / \mathrm{HDL}$ ratio, fibrinogen and CRP.

Kelly et al. ${ }^{32}$ rated an aerobic 8 weeks protocol training, based on performed bicycle exercises. It was found improvement in arterial endothelial function in overweight adolescents. Also using exercise program in ergometer cycle, Rosa et al. ${ }^{26}$ verified that obese adolescents and adolescents with type one diabetes, there was decrease in IL-6 concentrations and better metabolic control.

Physical exercise can reduce cardiovascular risks to mitigate and ameliorate the metabolic effects of dyslipidemia, diabetes and obesity ${ }^{47}$. Shortly after exercise can occur increases in circulating levels of IL-6 derived from muscle that induces the production of IL-1 ra e IL-10, which are anti-inflammatory cytokines, and TNF-a cytokine production inhibition ${ }^{48}$. Also the physical exercise can increase lipoprotein lipase enzyme activity, catabolism of triglycerides, increase HDL-C ${ }^{49}$, increasing the blood concentration of free fatty acids and the stimulation of hormonal control of adipose-tissue lipolysis ${ }^{50}$.

The analyzed studies used mainly incentive to increase practice of aerobic activity. Aerobic exercises performed regularly induces secretion substances such as neurotransmitters, soluble leptin receptor, $\beta$-endorphins and nitric oxide, which are beneficial for metabolic and cardiovascular system ${ }^{51,52}$

Sigal et al. ${ }^{30}$ showed that the group of adolescents that adhering combined aerobic and resistance exercise training tended to be superior to aerobic training alone in decreasing percentage body fat, waist circumference and BMI. However, no significant intergroup differences were observed in the levels of fasting insulin, fasting or 2-hour glucose, triglycerides, glycated hemoglobin, $\mathrm{HDL}-\mathrm{C}$, or LDL-C or total cholesterol.

It is important to emphasize that the evaluation period of exercise effect on cardiometabolic markers may influence the interpretation of results. Byrne et al. ${ }^{24}$ rated military recruits with a mean age of 18.8 $( \pm 0.11)$ years, healthy and normal, and proposed an PA protocol for 10 weeks, five weeks general PA and 5 weeks of exhaustive PA. After 10 weeks of exercises, there was decrease in fibrinogen and CRP levels, however, the group evaluation after 12 hours showed an increase in CRP levels. In individuals evaluated after four to five weeks after intense exercise decreased CRP levels.

According to Teodoro et al. ${ }^{53}$ aerobic exercise improves the organic defense systems against atherosclerosis by decreasing oxidative stress and increasing the synthesis of antioxidant enzymes; Vasodilation increase via nitric oxide (NO) and endothelial nitric oxide synthase, and decreased systemic inflammation with the production of pro-inflammatory cytokines and increase in anti- inflammatory factors. Acute and intense aerobic exercise can increase the risk of developing cardiovascular events, and chronic and moderate exercise can play in the prevention of atherosclerotic process.

Regarding the items with cross-sectional design 5 showed a relationship between the level of AF and / or sedentary behavior and cardiometabolic markers ${ }^{12,23,34,35}$ (Table 3) Martinez-Gomez et al. ${ }^{12}$ found that the entire group with higher levels of PA, for accelerometer and iPAQ, had lower levels of CRP, C3 and C4.

Countryman et al. ${ }^{34}$ investigated the influence of behavioral risk factors and lifestyle on the metabolic syndrome and inflammation of adolescents of both sexes. The proposed model found that lifestyle factors, decreased physical activity, increased fatigue, duration and poor sleep quality were factors associated with increased risk of metabolic syndrome and inflammation (CRP, IL-6 and fibrinogen).

Three studies showed an association between sedentary behavior and cardiometabolic markers ${ }^{23,24,34}$. Martinez-Gomez et al. ${ }^{25}$ found that time spent watching television was associated with endothelial adhesion molecules, E-selectin and L-selectin. Ischander et al. ${ }^{33}$ found that IL-6, IL-1 ra and TNF-a had significantly higher concentrations in sedentary groups. Velásquez-Rodriguez et al. ${ }^{23}$ showed risk of insulin resistance amongst overweight adolescents increases significantly when they watch 3 or more hours/day of television $(O R=1.7$, 
$\mathrm{Cls}=0.98-2.8, \mathrm{p}=0.033)$. Also, overweight status and insulin resistance were associated with higher levels of inflammation (high-sensitive CRP $\geq 1 \mathrm{mg} / \mathrm{L}$ ) and cardiovascular risk according to arterial indices.

Physical inactivity is an important factor that may contribute to the increase in obesity also among teenagers. Excess weight was a factor directly related to cardiometabolic markers concentration in cross-sectional studies analyzed. Maggio et al. ${ }^{35}$ observed correlation between percentage of body fat and resistin. Wang et al..$^{38}$ found that phospholipids fatty acid was inversely proportional to the concentrations of CRP and IL-6.

Steene-Johannessen et al. ${ }^{39}$ found a correlation between waist circumference and CRP concentrations, leptin, PAI-1 and hepatocyte growth factor. Al-Isa et al. ${ }^{40}$ showed that adolescents with overweight / obesity were 33 times more likely to have high levels of CRP and 2 times more likely to intercellular adhesion molecule (ICAM-1). Nadeau et al. ${ }^{37}$ found that CRP and IL-6 were higher in adolescents with type 2 diabetes compared to obese and control groups.

Abdominal fat accumulation and hyperinsulinemia are also associated with a thrombogenic and inflammatory profile. Increased concentrations of fibrinogen and PAl-1 have been reported in patients with visceral obesity, increasing the risk of thrombosis in these patients. Although there is evidence that there may be strong relation of hyperinsulinemia with high concentrations of PAl-1, it is possible that this mechanism is dependent on the metabolic status and the amount of body fat ${ }^{54}$.

Wang et al. ${ }^{38}$ found that phospholipids fatty acid was inversely proportional to CRP and IL-6 concentrations. Maggio et al. ${ }^{34}$ found that resistin concentrations were associated with IL-6 concentrations and endothelial biomarker (ET-1). Resistin adipokine is a recently identified belongs to a family of cysteine-rich proteins, found in inflammatory regions. It is specifically expressed in white adipose tissue and its secretion is strongly associated with insulin resistance ${ }^{55}$.

Other factors observed were sex and age. Al-Isa et al. ${ }^{40}$ found that boys had higher CRP levels, ICAM-1 and vascular cell adhesion molecule-1 (VCAM-1) compared to girls. These authors also observed that adolescents younger than 14 years had 3 times the concentration of ICAM1 that adolescent over 14 years. Balagopal et al..$^{10}$ found that age may be an important modulator of cardiometabolic markers concentrations. These researchers explain that the concentrations of IL-6, TNF-a, ICAM-1 and Eselectin appear to be higher in children than in healthy adults.

Gender differences were also found in post-pubertal children to E-selectin and VCAM-1, which were higher in obese male children than obese female children ${ }^{56}$. The literature also shows that in childhood and adolescence there is difference in plasma leptin levels between the sexes: in girls, leptin levels gradually increase with age, with weight gain and body fat, while in boys there is a progressive decrease $\mathrm{e}^{54}$.

The difference in leptin concentration and other biomarkers may become more evident in prepubertal phase ${ }^{10}$. Probably due to hormonal differences that testosterone has a negative correlation with leptin levels, explain these differences ${ }^{57}$. Therefore, we can see the care that must be taken when interpreting the levels of cardiometabolic markers at younger ages, so this is considered an important topic for further study ${ }^{10}$.

In general five studies $18,21,22,27,37$ considerate the maturity stage above 4. This aspect can be important for analyze the participants in same period of the adolescence, taking into account the sudden bodily changes that can happen in puberty. However, the reliability self-assessment of pubertal maturation has shown conflicting results. According to Ramussen et al.' the pubertal assessment by the child or the parents is not a reliable measure of exact pubertal staging and should be augmented by a physical examination.
Many questionnaires were used to assess the level of physical activity. The instruments used were: Seven-Day Physical Activity Recal|135, International Physical Activity questionnaire ${ }^{25}$, PA questionnaire ${ }^{37,58}$, Pediatric Assessment Questionnaire of habitual physical activity level|37, Three-Day Physical Activity Recall (3DPAR) ${ }^{23}$ and questionnaire constructed for practice evaluation, time and length of time the practice of sports during the week ${ }^{40}$.

Sedentary behavior was assessed by time watching TV, playing video game and painting. It was reported sedentary behaviors in daily 3 DPAR. Questionnaires, diaries and self-reports are indirect methods of PA level that may be biased in their results, limiting their relation to cardiometabolic markers ${ }^{23,25}$.

The accelerometer was used in three described studies ${ }^{12,25,36}$. In two of these studies was found a significant association between PA and cardiometabolic markers concentration. According to Corder et al. ${ }^{58}$, accelerometry is able to properly assess the PA and its association with health results, however, the accuracy can be reduced to assess derived measures such as energy expenditure. Physical fitness was also assessed through measures of maximum oxygen consumption $\left(\mathrm{VO}_{2}\right)^{9,26,34,39}$. The tests used to evaluate the $\mathrm{VO}_{2}$ in cross-sectional studies were exhaustion test performed on a cycle ergometer and Cooper method on track.

\section{Strengths and limitations}

This research did a comprehensive synthesis of methods of intervention and observational analyzes regarding the impact of the PA and Physical Exercise on cardiometabolic marks and cardiovascular risk factors on young population. Different constraints were addressed between items with longitudinal and cross-sectional design. The most prominent limitation in longitudinal studies was related to reduced samples, lack of dietary prescription control and the volume and intensity of physical exercise ${ }^{22,29,33}$. In cross-sectional studies was the impossibility of generalization and cause and effect relationship between PA (in general aspects) and cardiometabolic marker concentrations in adolescents.

However, this systematic review showed that others factors can is associated with the relationship between PA and cardiometabolic markers, such as: food consumption ${ }^{25,37}$ sex hormones ${ }^{36}$, socioeconomic level ${ }^{37}$ and insulin resistance influence ${ }^{55}$. Important considerations should be carefully observed as PA components change (type, intensity, frequency and volume), sedentary behavior and food habits of adolescents.

\section{FINAL CONSIDERATIONS}

It can be seen in most articles that PA may influence or be related to inflammatory markers concentration in adolescents, particularly those with overweight / obesity. Among the articles that correlate with inflammatory markers, the majority (11) had longitudinal design. All studies that proposed lifestyle change observed decrease in inflammatory markers concentration.

However, studies with representative sample size and precise control in assessing the level of physical activity and / or exercise are required to determine accurately the changes that the more active lifestyle can have on inflammatory process, as well as in others risk factors for cardiometabolic diseases in adolescents.

\section{ACKNOWLEDGEMENT}

Support: Foundation Support Research of Minas Gerais (FAPEMIG) and National Counsel of Technological and Scientific Developmen (CNPq).

All authors have declared there is not any potential conflict of interests concerning this article. 
AUTORES' CONTRIBUTIONS: All authors contributed individually and significantly to the completion of the manuscript. VPNM (0000-0002-2037-057)* participated of the project design, search for articles, writing, analysis and interpretation of data. PRSA (0000-0002-4327-9190)* participated in drafting the article or revising it critically for important intellectual content and final approval of the version to be published. NCBO (0000-0002-5038-5530)* participated in the analysis of the results and critical review of the intellectual content. MCGP $(0000.0003 .4665 .7043)^{*}$ participated in drafting the article or revising it critically for important intellectual content and final approval of the version to be published. SEP (0000-0003-0656-1485)* participated of the project design, drafting, analysis, data interpretation and final approval of the version to be published. All authors contributed to the intellectual concept and reviewed the article before submission. ${ }^{*}$ Number ORCID (Open Researcher and Contributor ID). ${ }^{*}$ ORCID (Open Researcher and Contributor ID).

\section{REFERENCES}

1. Rasmussen AR, Wohlfahrt-Veje C, Tefre de Renzy-Martin K, Hagen CP, Tinggaard J, Mouritsen A, et al. Validity of self-assessment of pubertal maturation. Pediatrics. 2015;135(1):86-93.

2. Priore SE, Faria FR, Franceschini SCC. Adolescência. In: Faria ER, Pereira PF, Oliveira RMS, Priore SE, Franceschini SC. Nutrição e saúde na adolescência. São Paulo: Rubio; 2010. p. 1-7.

3. Hopps E, Caimi G. Exercise in obesity management. J Sports Med Phys Fitness. 2011;51 (2):275-82.

4. lannotti RJ, Wang J. Trends in physical activity, sedentary behavior, diet, and BMI among US adolescents, 2001-2009. Pediatrics. 2013;132(4):606-14.

5. Saha AK, Sarkar N, Chatterjee T. Health consequences of childhood obesity. Indian J Pediatr. 2011;78(11):1349-55.

6. Karch I, Olszowska M, Tomkiewicz Pająk L, Drapisz S, Łuszczak J, Podolec P. The effect of physical activity on serum levels of selected biomarkers of atherosclerosis. Kardiol Pol. 2013;71(1):55-60.

7. Wu CK, Yang CY, Lin JW, Hsieh HJ, Chiu FC, Chen JJ, et al. The relationship among central obesity, systemic inflammation, and left ventricular diastolic dysfunction as determined by structural equation modeling. Obesity (Silver Spring). 2012;20(4):730-7.

8. Skinner AC, Steiner MJ, Henderson FW, Perrin EM. Multiple markers of inflammation and weight status: cross-sectional analyses throughout childhood. Pediatrics. 2010;125(4):e801-9.

9. Buchan DS, Ollis S, Young JD, Thomas NE, Cooper SM, Tong TK, et al. The effects of time and in tensity of exercise on novel and established markers of CVD in adolescent youth. Am J Hum Biol. 2011;23(4):517-26.

10. Balagopal PB, de Ferranti SD, Cook S, Daniels SR, Gidding SS, Hayman LL, et al. Nontraditional risk factors and biomarkers for cardiovascular disease: mechanistic, research, and clinical considerations for youth: a scientific statement from the American Heart Association. Circulation. 2011;123(23):2749-69.

11. da Silva Alves E, de Aquino Lemos V, Ruiz da Silva F, Lira FS, Dos Santos RV, Rosa JP, et al. Low-grade inflammation and spinal cord injury: exercise as therapy? Mediators Inflamm. 2013;2013:971841.

12. Martinez-Gomez D, Gomez-Martinez S, Ruiz JR, Diaz LE, Ortega FB, Widhalm K, et al. Objectivelymeasured and self-reported physical activity and fitness in relation to inflammatory markers in European adolescents: the HELENA Study. Atherosclerosis. 2012;221(1):260-7.

13. Petersen AM, Pedersen BK. The anti-inflammatory effect of exercise. J Appl Physiol (1985). 2005;98(4):1154-62

14. Rosseti MB, Brito RR, Norton RC. Prevenção primária de doenças cardiovasculares na obesidade infantojuvenil: efeito anti-inflamatório do exercício físico. Rev Bras Med Esporte. 2009;15(6):472-5.

15. Vasconcellos F, Seabra A, Katzmarzyk PT, Kraemer-Aguiar LG, Bouskela E, Farinatti P. Physical activity in overweight and obese adolescents: systematic review of the effects on physical fitness components and cardiovascular risk factors. Sports Med. 2014;44(8):1139-52.

16. Moher D, Liberati A, Tetzlaff J, Altman DG; PRISMA Group. Preferred reporting items for systematic reviews and meta-analyses: the PRISMA statement. PLoS Med. 2009;6(7):e1000097.

17. Minayo MCS. Social research: theory, method and creativity. 26a. ed. Petropolis, RJ: Vozes; 2007.

18. Lovely R, Hossain J, Ramsey JP, Komakula V, George D, Farrell DH, et al. Obesity-related increased $\gamma^{\prime}$ fibrinogen concentration in children and its reduction by a physical activity-based lifestyle intervention: a randomized controlled study. J Pediatr. 2013;163(2):333-8.

19. Rynders C, Weltman A, Delgiorno C, Balagopal P, Damaso L, Killen K, et al. Lifestyle intervention improves fitness independent of metformin in obese adolescents. Med Sci Sports Exerc. 2012;44(5):786-92.

20. Garanty-Bogacka B, Syrenicz M, Goral J, Krupa B, Syrenicz J, Walczak M, et al. Changes in inflammatory biomarkers after successful lifestyle intervention in obese children. Endokrynol Pol. 2011;62(6):499-505.

21. Balagopal PB, Gidding SS, Buckloh LM, Yarandi HN, Sylvester JE, George DE, et al. Changes in circulating satiety hormones in obese children: a randomized controlled physical activity-based intervention study. Obesity (Silver Spring). 2010;18(9):1747-53.

22. Balagopal P, George D, Patton N, Yarandi H, Roberts WL, Bayne E, et al. Lifestyle-only intervention attenuates the inflammatory state associated with obesity: a randomized controlled study in adolescents. J Pediatr. 2005;146(3):342-8.

23. Velásquez-Rodríguez CM, Velásquez-Villa M, Gómez-Ocampo L, Bermúdez-Cardona J. Abdomina obesity and low physical activity are associated with insulin resistance in overweight adolescents: a cross-sectional study. BMC Pediatr. 2014;14:258.

24. Byrne DJ, Jagroop IA, Montgomery HE, Thomas M, Mikhailidis DP, Milton NG, et al. Lipoprotein (a) does not participate in the early acute phase response to training or extreme physical activity and is unlikely to enhance any associated immediate cardiovascular risk. J Clin Pathol. 2002;55(4):280-5.

25. Martinez-Gomez D, Eisenmann JC, Healy GN, Gomez-Martinez S, Diaz LE, Dunstan DW, et al. Sedentary behaviors and emerging cardiometabolic biomarkers in adolescents. J Pediatr. 2012;160(1):104-10.

26. Rosa JS, Oliver SR, Flores RL, Ngo J, Milne GL, Zaldivar FP, et al. Altered inflammatory, oxidative, and metabolic responses to exercise in pediatric obesity and type 1 diabetes. Pediatr Diabetes. 2011;12(5):464-72

27. Balagopal P, Graham TE, Kahn BB, Altomare A, Funanage V, George D. Reduction of elevated serum retinol binding protein in obese children by lifestyle intervention: association with subclinical inflammation. J Clin Endocrinol Metab. 2007;92(5):1971-4.

28. Nascimento H, Costa E, Rocha-Pereira P, Rego C, Mansilha HF, Quintanilha A. Cardiovascular risk fac tors in portuguese obese children and adolescents: impact pf small reductions in body mass index imposed by lifestyle modifications. Open Biochem J. 2012;6:43-50.

29. Meyer AA, Kundt G, Lenschow U, Schuff-Werner P, Kienast W. Improvement of Early Vascular Change and Cardiovascular Risk Factors in Obese Children After a Six-Month Exercise Program. Journal of the American College of Cardiology.2006;48(9):e1865-e1870. doi:10.1016/j.jacc.2006.07.035.
30. Sigal RJ, Alberga AS, Goldfield GS, Prud'homme D, Hadjiyannakis S, Gougeon R, et al. Effects of aerobic training, resistance training, or both on percentage body fat and cardiometabolic risk markers in obese adolescents: the healthy eating aerobic and resistance training in youth randomized clinica trial. JAMA Pediatr. 2014;168(11):1006-14

31. Barbeau P, Litaker MS, Woods KF, Lemmon CR, Humphries MC, Owens S, et al. Hemostat ic and inflammatory markers in obese youths: effects of exercise and adiposity. J Pediatr. 2002;141(3):415-20.

32. Kelly AS, Wetzsteon RJ, Kaiser DR, Steinberger J, Bank AJ, et al. Inflammation, insulin, and endothelia function in overweight children and adolescents: the role of exercise. J Pediatr. 2004;145(6):731-6.

33. Ischander M, Zaldivar F Jr, Eliakim A, Nussbaum E, Dunton G, Leu SY, et al. Physical activity, growth, and inflammatory mediators in BMI-matched female adolescents. Med Sci Sports Exerc 2007;39(7):1131-8

34. Countryman AJ, Saab PG, Llabre MM, Penedo FJ, McCalla JR, Schneiderman N. Cardiometabolic risk in adolescents: associations with physical activity, fitness, and sleep. Ann Behav Med. 2013;45(1):121-31

35. Maggio AB, Wacker J, Montecucco F, Galan K, Pelli G, Mach F, et al. Serum resistin and inflammatory and endothelial activation markers in obese adolescents. J Pediatr. 2012;161(6):1022-7.

36. May AL, Kuklina EV, Yoon PW. Prevalence of cardiovascular disease risk factors among US adolescents, 1999-2008. Pediatrics. 2012:129(6):1035-41.

37. Nadeau KJ, Zeitler PS, Bauer TA, Brown MS, Dorosz JL, Draznin B, et al. Insulin resistance in adolescents with type 2 diabetes is associated with impaired exercise capacity. J Clin Endocrinol Metab. 2009;94(10):3687-95.

38. Wang H, Steffen LM, Vessby B, Basu S, Steinberger J, Moran A, Jacobs JDR, Hong CP, Sinaiko AR. Obesity Modifies the Relations Between Serum Markers of Dairy Fats and Inflammation and Oxidative Stres Among Adolescents. Obesity. 2011; (19):e2404-e2410. doi: 10.1038/oby.2011.234.

39. Steene-Johannessen J, Kolle E, Reseland JE, Anderssen SA, Andersen LB. Waist circumference is related to low-grade infl ammation in youth. International Journal of Pediatric Obesity.2010;5:e313-e319. do: 10.3109/17477160903497035.

40. Al-Isa AN, Thalib L, Akanji AO. Circulating markers of inflammation and endothelial dysfunction in Ara adolescent subjects: Reference ranges and associations with age, gender, body mass and insulin sensitivity. Atherosclerosis.2010;208:e543e549_doi:10.1016/j.atherosclerosis.2009.07.056

41. Hackam DG, Anand SS. Emerging risk factors for atherosclerotic vascular disease: a critical review of the evidence. JAMA. 2003;290(7):932-40.

42. Allison MA, Jensky NE, Marshall SJ, Bertoni AG, Cushman M. Sedentary behavior and adiposity-as sociated inflammation: the Multi-Ethnic Study of Atherosclerosis. Am J Prev Med. 2012;42(1):8-13.

43. Kasapis C, Thompson PD. The effects of physical activity on serum C-reactive protein and inflammatory markers: a systematic review. J Am Coll Cardiol. 2005;45(10):1563-9.

44. Devaraj S, Singh U, Jialal I. The evolving role of C-reactive protein in atherothrombosis. Clin Chem 2009;55(2):229-38.

45. Fröhlich G, Pott W, Albayrak Ö, Hebebrand J, Pauli-Pott U. Conditions of long-term success in a lifestyle intervention for overweight and obese youths. Pediatrics. 2011;128(4):e779-85.

46. Paoletti R, Bolego C, Poli A, Cignarella A. Metabolic syndrome, inflammation and atherosclerosis. VasC Health Risk Manag. 2006;2(2):145-52.

47. Armstrong N. Aerobic fitness of children and adolescents. J Pediatr (Rio J). 2006;82(6):406-8.

48. Hamer M, Stamatakis E. Physical activity and risk of cardiovascular disease events: inflammatory and metabolic mechanisms. Med Sci Sports Exerc. 2009;41(6):1206-11.

49. Guedes DP, Rocha GD, Silva AJ, Carvalhal IM, Coelho EM. Effects of social and environmental determinants on overweight and obesity among Brazilian schoolchildren from a developing region. Rev Panam Salud Publica. 2011;30(4):295-302

50. Gottlieb MGV, Bonardi G, Moriguchi EH. Fisiopatologia e aspectos inflamatórios da aterosclerose Scientia Medica. 2005;15(3):203-7.

51. Oliveira CL, Mello MT, Cintra IP, Fisberg M. Obesidade e síndrome metabólica na infância e adolescência. Rev Nutr. 2004;17(2):e237-e245

52. Guimarães DED, Sardinha FLC, Mizurini DM, Tavares CMG. Adipocitocinas: uma nova visão do tecido adiposo. Rev Nutr. 2007;20(5)549-59.

53. Teodoro BG, Natali AJ, Fernandes SAT. Peluzio MCG. A Influência da Intensidade do Exercício Físico Aeróbio no Processo Aterosclerótico. Rev Bras Med Sporte. .2010;16(5):383-7.

54. Kapiotis S, Holzer G, Schaller G, Haumer M, Widhalm H, Weghuber D, et al. A proinflammatory state is detectable in obese children and is accompanied by functional and morphological vascular changes. Arterioscler Thromb Vasc Biol. 2006;26(11):2541-6.

55. Garcia-Mayor RV, Andrade MA, Rios M, Lage M, Dieguez C, Casanueva FF. Serum leptin levels in norma children: relationship to age, gender, body mass index, pituitary-gonadal hormones, and pubertal stage. J Clin Endocrinol Metab. 1997;82(9):2849-55.

56. Paffenbarger RS Jr, Blair SN, Lee IM, Hyde RT. Measurement of physical activity to assess health effects in free-living populations. Med Sci Sports Exerc. 1993;25(1):60-70

57. Osuna JA, Gómez-Pérez R, Arata-Bellabarba G, Villaroel V. Relationship between BMI, total testosterone, sex hormone-binding-globulin, leptin, insulin and insulin resistance in obese men. Arch Androl. 2006;52(5):355-61.

58. Corder K, Brage S, Ekelund U. Accelerometers and pedometers: methodology and clinical application Curr Opin Clin Nutr Metab Care. 2007;10(5):597-603. 